WHAT IT MEANS TO BE HUMAN 



\title{
WHAT IT MEANS TO BE human
}

THE CASE FOR THE BODY

IN PUBLIC BIOETHICS

\section{O. Carter Snead}

\author{
III \\ III \\ Harvard University Press \\ Cambridge, Massachusetts - London, England \\ 2020
}


Copyright (C) 2020 by the President and Fellows of Harvard College All rights reserved

Printed in the United States of America

First printing

Jacket design: Lisa Roberts

Jacket illustration: Leonello Calvetti/Science Photo Library

$$
\begin{gathered}
9780674250772 \text { (EPUB) } \\
9780674250789 \text { (MOBI) } \\
9780674250796 \text { (PDF) }
\end{gathered}
$$

The Library of Congress has cataloged the printed edition as follows:

Names: Snead, O. Carter, author.

Title: What it means to be human : the case for the body in public bioethics/O. Carter Snead.

Identifiers: LCCN 20200 IIII | ISBN 9780674987722 (cloth) Subjects: LCSH: Human body—Law and legislation-United States. | Bioethics-United States. | Abortion—Law and legislation-United States. | Human reproductive technology—Law and legislation—United States. Terminal care-Law and legislation-United States. | Human experimentation in medicine-Law and legislation-United States. |Medical laws and legislation-United States.

Classification: LCC KF390.5.H85 $\mathrm{S}_{4} 2020$ | DDC ${ }_{174.20973-d c 23}$

$\mathrm{LC}$ record available at https://lccn.loc.gov/20200IIII 
for Leigh 
